\title{
European markets of liquid natural gas: policy challenges and energy diplomacy
}

UDC 327.82

DOI https://doi.org/10.24195/24149616.2021-2.19

Moshenets Ihor Oleksandrovych Postgraduate Student at the Center for Security Studies

National Institute for Strategic Studies Pyrohova str., 7a,

Kyiv, Ukraine

\begin{abstract}
Technological peculiarities of liquid natural gas (LNG) transportation have important influence on energy geopolitics, providing an alternative toward onshore pipelines way for gas trading. The purpose of this article is to explain the interplay between agency of key regional political actors and economic functioning of European LNG market. The method of this research would be process tracing. Three basic claims of our analysis are follows. First, there are four key determinants of the future role of LNG in European energy mix: increasing of internal demand due to the gradual depletion of internal gas fields and limiting coal usage; technological breakthrough of shale gas industry in USA; conditions related to spread between European and Asian LNG prices and between cost of LNG and pipeline deliveries in Europe. As for now, European LNG market still plays the balancing role on the world scale being still less attractive in pricing terms destination for LNG supplies than Eastern Asia. Second, European Commission's powers in regard to LNG industry have the form of partial financing of infrastructure construction and monitoring the compliance of market players to European energy law. Brussels have avoided political intrusions in the industry to define which particular countries should be in priority as exporters. In turn, member-states play the key role in defining infrastructure priorities, which leaves them the opportunity to integrate their own strategic energy considerations in the wider EU-level framework. Despite considerable environmentalist opposition to some projects, in general, EU policies were influential for further expanding of LNG import capacities during the last decade. Third, LNG exporters have opportunities to influence the ways of increasing own exports by the means of energy diplomacy. Nevertheless, the US and Russia have different strategies for exporting their LNG to Europe. US have used energy diplomacy in the framework of high-profile state-level meetings for both commercial and political reasons. Russian LNG strategy was built around contacts on the corporate level for finding partners among Western European companies without active involvement of state diplomacy but with the preservation of formal or informal control of Russian state over all its national LNG companies.
\end{abstract}

Key words: European Union, LNG, energy diplomacy, geopolitics.
Introduction. Liquid natural gas (LNG) is a steadily growing segment of natural gas markets, that is expanding - from 135 billion cubic meters in 2000 to 485 billion in 2019 [16]. Despite challenges brought by the Covid-19 pandemic for the LNG market, this source of energy still has all chances to remain competitive in the future.

Technological peculiarities of LNG transportation have an important influence on energy geopolitics by providing an alternative toward onshore pipelines way for gas trading.

LNG is natural gas that is transformed to liquid form in the process of liquefaction (cooling to minus 162 degrees Celsius), then transported by ships in metal containers and after its regasification is used again for transportation via pipelines or trucks. Export and import terminals where, correspondingly, liquefaction and regasification are performed, serve as the crucial gatekeeper points for a network that bridges gas suppliers and gas buyers by creating principally new spatial connections. Therefore LNG terminals are strategic places of geoeconomic influence, in which power constellations in world energy markets are geographically rearranged, mediating the influence of various states and firms.

Purpose and tasks. The purpose of this article is to explain the interplay between the agency of key regional political actors and the economic functioning of European LNG markets by distinguishing the core geopolitical interests and motivation influencing the decision of key market players and state institutions in charge of the relevant policy area.

In order to reach mentioned research goal, we need to concentrate on such tasks as 1) distinguishing the structural role of the European region on the scale of the global LNG market by taking into account changes in LNG internal demand and external supply; 2) defining the extent of European Commission's control over the functioning of regional LNG market as well as the role of member states in shaping EU position in this sphere; 3) examining the role and character of diplomatic activities performed by major LNG supplying countries for promoting their export.

Methods of research. The core method of this research would be process tracing. The usage of this method allows building a coherent narrative by selecting the relevant for the research topic historic facts and connecting them in a unified chain of cause-effect relations.

Results. The place of Europe on the global LNG market. The EU is after Japan (102 bcm) and China (91 bcm) the third-largest LNG market in the world, having imported $84 \mathrm{bcm}$ of LNG after regasification in 2020 [24, p. 3]. As of April 2021, on the EU territory function 25 regasification terminals (seven in Spain, four in France, three in Italy, three in Finland, and one in each of the eight countries: Belgium, Croatia, Greece, Lithuania, Malta, Netherlands, Poland, Portugal). Their overall annual regasification capacity is $255 \mathrm{bcm}$ [21] which provides the potential to cover more than half of EU 
natural gas annual import demand (326 bcm of natural gas was imported in 2020 in overall [24, p. 3]). But, as we can see from comparing the overall technical capacity with factual amounts of regasified gas, the utilization rate of existing capacities is low, accounting only for nearly onethird of the whole. It is not something unusual but rather typical situation. LNG terminals serve, firstly, as reserve capacities for providing additional amounts of natural gas in times of high market demand, and, secondly, as a potential alternative source needed for greater supply diversification and strengthening bargaining positions with onshore pipeline exporters.

Four factors are defining the standing of the EU on the global LNG market.

The first factor is the rise of European interest in more gas supplies which makes LNG a viable option for diversification of supplies. The combination of three factors play here a crucial role: the need to limit the usage of coal from the considerations of low-carbon development; the inability of renewable energy (wind and solar) to guarantee the stable energy flow during the different times of a day [12, p. 13-14]; planned refusal from nuclear energy of such countries, as Germany. On the other side, the declining of internal European gas reserves also partially contributed to the growing gas demand, especially in Western Europe: Dutch Groningen field, the biggest gas field on the territory of EU, should steadily shorten its output and is planned to be shut down until 2030 [28, p. 17]. The role of natural gas as transitional fuel on the road of energy transformation toward zero-carbon growth is widely discussed on the different levels of the EU governance system especially since the proclamation of the European Green Deal political course in 2019. The results of political deliberation of the future role of natural gas are yet to be defined.

The second major factor which changed the situation on European LNG markets was the shale gas revolution in the USA. The invention of the new technology of hydraulic fracturing allowed the US to expand its gas and oil production and provide also larger amounts of gas for sale to the world markets [15, p. 75].

The third factor is a price gap between European and East Asian LNG markets. Despite the fact, that a significant part of LNG deliveries are made in the framework of long-term oil price-linked contracts, short-time supplies for the spot market are the most decisive factor influencing whether the overall LNG import would relatively increase or decrease in comparison to analogous periods in the past. The basic logic of spot supplies is that exporters prefer to route their cargos to those markets which are prepared to buy LNG for the highest price. Eastern Asia is more dependent on LNG due to the lack of pipeline alternatives similar to those, available in Europe (especially in such countries as Japan and South Korea). Therefore, Asian prices are usually higher than European ones. When the prices converge, Europe's LNG market can expand, but when the spread increases (usually in favor of Asian markets), European LNG import usually falls.
Two periods of significant price difference between the two regions were observed during the last decade. The first one appeared after the Fukushima disaster in Japan in 2011, which have forced this country to abandon temporarily its nuclear power facilities [5, p. 151-152]. The second big divergence of prices occurred at the end of 2020 as the result of a "perfect storm" - faster postpandemic economic recovery in Eastern Asia, abnormally cold winter, increase of pricing for transportation [17].

The fourth important factor for the European LNG market is the competition of LNG with pipeline gas, especially in the context of economic rivalry between the USA and Russia. The competitiveness of each of the two sides against another one depends on the difference between US and European spot prices [2, p. 3] and the difference between European spot prices and Russian oil-linked contract prices. In the situation of a low-price environment (under $\$ 40$ per barrel), Russian pipeline deliveries are more competitive, whether under higher oil prices economic attractiveness of US LNG considerably increases [6, p. 3].

However, it is highly unlikely, that LNG import would remove Russian pipeline gas with its quite favorable pricing conditions from EU energy mix. Also, in the situation of potential competition with LNG, Russian Federation was forced to transform its energy strategy during the 2010s. Russia has moved from revenue maximization to market share preservation - preparedness to make discounts in order not to lose its export markets [19, p. 212-217]. That meant for Gazprom to trade more gas on the spot market and make export contracts more flexible.

Such measures, despite preserving Russia's economic influence, could be seen as effective in strategic deterring of Russian Federation. These changes limit Kremlin's ability to manipulate politically gas trade. Also, Moscow's need to lower gas prices decreases revenues from the gas export, which in long run weakens the Russian economy.

Supranational and national policy responses for developing the LNG industry. The current legal framework of LNG terminals' operation is established by article 36 of the third gas directive. The main difference from the pipeline gas markets is that European legislation does not require the unbundling of LNG terminals. Unbundling means division of production from transporting and marketing functions in vertically integrated energy companies [26, p. 24]. Concerning LNG terminals, the absence of unbundling prescriptions means that they may be operated by the same large state monopolists which control main gas extraction facilities of their countries.

Nevertheless, the cornerstone of the legal regime in European gas markets, third-party access requirement, remains valid for the LNG industry. This norm presupposes the ability of any company to contract the usage of the terminal for its deliveries in the case of abilities of free transport capacities [26, p. 19]. Only six terminals, which constitute less than one-quarter of all terminals, are exempted from the conventional regulatory regime since 2011 [30, p. 2]. 
Apart from market-based regulations, during the last years, EU policymakers tried also to address the geopolitical challenges by the elaboration of the EU global action plan and defining the role of energy in it. The LNG strategy's three main pillars were the development of needed infrastructure; completing the internal liberalized gas market; intensifying diplomatic dialogue with current and potential LNG suppliers [7, p. 2-3]. It directly recognized that Central European member states are dependent on Russia as the sole supplier and that the development of infrastructure in this geographical area should enable better access of LNG to their national energy markets, which would diversify their supplies [7, p. 2].

Nevertheless, this document still got some criticism. The Council of European Energy Regulators (CEER) in its analytical response to the strategy noticed, that the EU LNG strategy concentrates on the capacity approach without paying the needed attention to the commoditybased approach. The regulators stressed that possessing a free place in the LNG import terminals does not automatically grant that they could be filled immediately by the needed amount of LNG in times of energy supply crisis [4, p. 5]. Also, CEER pointed out that strategy does not give any exact information about what companies, countries, or regions should play the defining role in the strategy, as well as what is the detailed technical emergency plan of optimal LNG usage in the time of emergency with energy supply [4, p. 5].

Infrastructural development was considered as the priority in the further development of European LNG markets. Special institutional arrangements were created to facilitate this process. In 2011 was adopted a plan of Trans-European Network for Energy (TENE), which defined the general view for the development of infrastructure for the next decade. Since 2013 Commission publishes the lists of Projects of Common Interests $(\mathrm{PCl})$ for clarification of short-term priorities corresponding with a broader 10 year-plan. They include the most important infrastructure objects which improve the functioning of European markets and can obtain EU financing for their development. The representatives of member counties play a substantial role in the elaboration of PCl lists. The whole territory of the EU is divided into four subregional high level groups. They serve as the platforms for deliberations between energy ministers of neighboring countries about the most needed for construction infrastructure objects. The possible influence of particular projects on markets of other EU members is also taken into account in these meetings.

The $\mathrm{PCl}$ list is renewed every two years. European Commission has already adopted its four versions.

As of summer 2018, the EU has spent and was planning to spend in overall 638 million euros on LNG infrastructure until 2021 [9]. EU funding complements usually additional sources of funding (private or public) and normally accounts for $30-50 \%$ of overall projects' budget. The sources of funding are diversified. To the main of them belong Connecting Europe Facility, European Regional Development Fund, and the European Energy Recovery Programme.
The lists of $\mathrm{PCl}$ in different years concentrated on such basic LNG terminals as Shannon in Ireland, Swinoujscie in Poland, Klaipeda in Lithuania, Gothenborg in Sweden, Krk Island in Croatia, Constanta in Romania, Revithoussa, Alexandroupolis, and Aegean in Greece. Some projects included the full construction of the facility, why others were limited to the capacity extension or some type of technological expertise.

Baltic region and Balkans played in this regard the special role.

The LNG terminal in Swinoujscie opened in 2014 and changed the energy balance in the region. The inflow of LNG from Qatar and later also from the US allowed Poland to officially proclaim in November 2019 that since 2023 it would not buy the Russian gas [8]. The country plans to expand its LNG import even further: the project of another terminal in Gdansk was included in the last $\mathrm{PCl}$ list. The Polish pipeline interconnections with neighbouring countries were also much improved with using EU's financing which may make Poland a regional gas hub in the future.

Floating Storage Regasification Unit (FSRU) Independence in Lithuanian Klaipeda allowed the country to halve its import of Russian gas and to strengthen its bargaining position in commercial talks with Russian Gazprom, obtaining a 23\% discount from Gazprom for its pipeline gas [3, p. 189]. The basic long-term contract of supplies was concluded with Norwegian company Equinor.

Hungarian state owned company MVM Group launched cooperation with Adria LNG terminal in Croatia (Krk Island) reserving 1 bcm of its annual capacities from 2021 to 2027. Hungarian corporate customer already concluded an agreement with Shell on supplies in the amount of 0,25 bcm per year for the same period [13].

Nevertheless, not all previously planned projects were implemented. There were some of them which were blocked (Gothenburg project in Sweden and Cork in Ireland) or delayed (Shannon LNG in Ireland) due to the resistance against them organized by climate activists. The project of the LNG terminal in Romanian Constanta should have played an important role in the proposed in 2010 project of Azerbaijan-Georgia-Romania Interconnector which should combine pipeline and LNG supplies. The project of the Constanta LNG terminal was included in PCI List in 2013 but later was pulled out. For that were many reasons: higher geopolitical risk of LNG supplies due to the Russian annexation of Ukrainian Crimea; lack of needed capacities for this route in Azerbaijan after concentration on projects in Turkish direction; reorientation of Romania toward developing its gas fields on Black Sea shelf [11]

Diplomatic agency of LNG exporters to EU. The dynamic on the European LNG market is shaped not only by the Commission's measures but also by the strategic actions of the main LNG exporters. To the traditional exporters belonged Qatar, Algeria, Norway, Peru, Trinidad, and Tobago. However, during the last time, Russia and the USA were gaining in importance in this 
market obtaining the position in top-3 LNG exporters to the EU in 2019 [23, p. 18].

After the shale revolution, the US share in European LNG import is growing very fast - from $0.6 \%$ in 2016 [22, p. 12] to $22.6 \%$ in 2020 [24, p. 18]. Despite the considerable interests of Donald Trump's presidential administration in the development of the US LNG industry, the political motivations played a similarly important role: the US was aware of the geopolitical consequences of providing supply alternative for dependent on Russian export countries.

The US involvement in European gas markets could be conceptualized through the lenses of the three basic strategies. The first one provides direct diplomatic communication with the EU supranational institutions to get the political guarantees of enlarging the share of US LNG export. In this regard key event was the meeting of Donald Trump with Jean-Claude Juncker in July 2018 [14]. The President of the Commission made the public promise to the US President to build new LNG terminals, which would increase the European capacity to absorb more LNG imports.

Another strategy provided active diplomatic involvement on subregional diplomatic platforms. In 2017 Donald Trump visited the Warsaw Three Seas Initiative summit where he promoted for participant countries the idea of buying American LNG [10]. Speaking at 2018 Romanian Three Seas Initiative summit US Energy Secretary Rick Perry proclaimed the establishment of a new "Partnership of Transatlantic Energy Cooperation" [29]. In February 2020, during his speech at Munich Security Conference, US Secretary of the State Michael Pompeo announced the commitment to allocate 1 billion dollars for the infrastructural development in the framework of the Three Seas Initiative [27].

The third US strategy was to engage directly in international energy affairs in East-Central and SouthEastern Europe as the most dependent on Russian export regions. In 2018 Trump and Polish PresidentAndrzej Duda signed a memorandum about US-Polish cooperation in the energy sphere. After their meeting, Polish public company PGNIG concluded the contracts with three American companies on LNG supplies [28, p. 15]. In September 2019, with the involvement of Polish President, Ukrainian President Volodymyr Zelenskiy and US Energy Secretary Rick Perry signed a three-party memorandum that provided import of US LNG from Swinoujscie to Ukraine [18]. However, the conclusion of a bigger contract was not held despite the rumours of the talks on this issue [31]. After the first session of the US-Bulgarian strategic dialogue, held in January 2020, Bulgaria decided to buy a $20 \%$ stake in Greek company Gastrade to take part in Alexandroupolis LNG project and to obtain regasified LNG via Interconnector Greece-Bulgaria pipeline (Alexandroupolis LNG terminal is planned to begin its operation in 2023) [25].

Despite its diplomatic success, further involvement of the American state in promoting national LNG export is doubtful. The new presidential administration of Joseph
Biden is expected to shift US energy policies toward rapid decarbonization of the economy and limited usage of all types of fossil fuels.

Russia traditionally was the biggest European supplier of natural gas by using the conventional way of transportation via offshore or onshore pipelines. But recently, fearing the competition from LNG, it also significantly expanded its leverage in this segment of the market. Previously not even listed among the main LNG exporters to Europe, Russia became in 2020 the second-largest exporter with 20\% share $[24$, p. 3]. The destination analysis of Russian LNG supplies shows that LNG has the potential for reaching countries that were not the traditional buyers of Russian gas. (Spain and Portugal have not consumed Russian gas before but have ordered some short-time supplies of LNG) [24, p. 16].

Russia liberalized LNG export in 2013 [19, p. 202] and preserved Gazprom's export monopoly only in the segment of pipeline gas deliveries. However, only one private company, Novatek, used provided opportunity and started to play a profound role in developing Russian LNG projects. The key role for supplies for Europe plays the Yamal LNG project. Despite the original Novatek's owner's claims, that the company would sell their LNG from the Yamal project almost entirely to Asia, $80 \%$ of its export supplies in 2019 were destinated for Europe [34]. Russian private company has developed its network of corporate ties with European players. For example, French firm Total is a minority shareholder of Yamal LNG project (20\%). This project has logistics cooperation with Belgium's Zeebrugge LNG terminal operated by local company Flyxus. Both companies, Fluxys and Novatek, are co-shareholders of a planned LNG terminal in German Rostock on the shore of the Baltic Sea with a Russian company owning $49 \%$. However, its planned capacity is relatively small (0.3-0.7 bcm annually after regasification) and, due to the absence of plans about integrating terminal in a German grid system, its LNG deliveries could be used only for shipping fuel and small-scale truck transportation [20]. Both Gazprom and Novatek are active in developing liquefaction facilities in the area near the Baltic Sea in UstLuga, Vyborg, and Vysotsk.

It is worth admitting that the availability of two corporate players, private and public ones, does not mean weakened control of the Russian government over this area of external economic activities. Novatek is owned by Leonid Mikhelson. He is one of the richest Russian oligarchs with close ties to Russian political elites. Possible political considerations of Russian LNG export could be seen from Mikhelson's public statement made in 2019. He said then that his company is prepared to help Gazprom to meet its contract duties in the case when transit contract with Ukraine would not be agreed and pipeline Nord Stream-2 would fail to start in time to substitute Ukrainian route [33].

Gazprom also tried to develop LNG projects with a more pronounced geopolitical vision. Russian experts claimed that this facility would provide an alternative way for supplying Russian exclave in Kaliningrad, making it 
less dependent on gas transit through Lithuania. Also were expressed hopes that Marshall Vasilevsky could compete with the Klaipeda LNG terminal for Baltic markets [1]. However, this calculation proved itself misleading, as Gazprom decided to relocate this facility from Kaliningrad to other places eight months after its installation [32].

Conclusions. European LNG market plays a balancing role on the world scale being still less attractive in pricing terms destination for LNG supplies than Eastern Asia. The EU policy regulation of the LNG market reflected the market-oriented principles of the EU energy policy paradigm and have not presupposed an elaborated vision of LNG as a geopolitical tool. All strategic considerations remained in the area of infrastructure construction.

European Commission's powers regarding the LNG industry have the form of monitoring the compliance of market players to European energy law and partially financing infrastructure construction. On the other side, member-states play a key role in defining infrastructure priorities which leaves them the opportunity to integrate their own strategic energy considerations in the wider EU-level framework. Despite considerable societal opposition to some projects, EU policies were in general influential for further expanding of LNG import capacities during the last decade.

US and Russia have different strategies for exporting their LNG to Europe. The US uses energy diplomacy in the framework of high-profile state-level meetings for both commercial (selling surpluses of internal gas production) and political (countering Russian monopolistic influence used for blackmailing) reasons. On the other side, Russia sees LNG as only secondary to the pipelines way of delivering its own gas to Europe. Russian LNG strategy was built around contacts on the corporate level for finding partners among Western European companies without the active involvement of state diplomacy. Nevertheless, the preservation of informal control of the Russian state over the LNG industry is still a sign of possible geopolitical calculations standing behind commercial agreements of Russian companies.

\section{BIBLIOGRAPHY}

1. Bochkarev D. (2019). Floating Storage Regasification Unit (FSRU) in Kaliningrad: Scoring Several Goals with One Shot. Valdai Club. URL: https://valdaiclub.com/a/highlights/floating-storageregasification-unit-fsru/

2. Bordoff J., Losz A. (2016) If You Build It, Will They Come? The Competitiveness of US LNG in Overseas Markets. Center on Global Energy Policy of Columbia SIPA. URL: https://energypolicy.columbia.edu/ sites/default/files/Competitiveness $\% 20$ of $\% 20 U S \% 20$ LNG\%20in\%200verseas\%20Markets.pdf

3. Bros T. (2017). Global LNG Pricing Dynamics and Impact on Europe. In Hafner, Manfred; Tagliapietra Simone (eds). The European Gas Markets: Challenges and Opportunities. Palgrave Macmillan, 2017. P. 179-193.

4. CEER response to the European Commission's strategy for liquefied natural gas and gas storage. Council of European Energy Regulators. URL: https:// www.ceer.eu/documents/104400/-/-/22e2218f-f1242d30-fabd-b8d031879278
5. Corbeau, A.-S. (2017). Global LNG Market Outlook and Repercussions for Europe. In Hafner M., Tagliapietra S. (eds). The European Gas Markets: Challenges and Opportunities. Palgrave Macmillan, 2017. P. 147-179.

6. Corbeau A.-S., Yermakov V. Will There Be a Price War Between Russian Pipeline Gas and US LNG in Europe? European Gas Hub. URL: https:// www.europeangashub.com/wp-content/uploads/ attach_664.pdf

7. Communication from the Commission to the European Parliament, the Council, the European Economic and Social Committee and the Committee of the Regions on an EU strategy for liquefied natural gas and gas storage. European Commission. URL: https:// ec.europa.eu/energy/sites/ener/files/documents/1 EN ACT_part1_v10-1.pdf

8. Declaration of will to terminate Yamal Contract effective December 31, 2022. PGNIG. URL: http:/l en.pgnig.pl/news/-/news-list/id/declaration-of-will-toterminate-yamal-contract-effective-december-31-2022/ newsGroupld/1910852

9. European Union imports of U.S. Liquefied Natural Gas (LNG) are on the rise. European Commission. URL: https://ec.europa.eu/commission/presscorner/ detail/en/IP_18_4920

10. Gotev, G., Brzozowski, A. (2018). The Brief Three Seas, Two Leaders. Euractiv. URL: https:// www.euractiv.com/section/politics/news/the-brief-threeseas-two-leaders/

11. Gusilov E. (2019). Black Sea LNG: Dreams vs Reality. Romanian Energy Center. URL: https:// www.roec.biz/project/black-sea-Ing-dreams-vs-reality/

12. Hafner M., Tagliapetra S. (2017). The Role of Natural Gas in the EU Decarbonization Path. In Hafner, Manfred; Tagliapietra, Simone (eds). The European Gas Markets: Challenges and Opportunities. Palgrave Macmillan, 2017, P. 1-24.

13. Hungary concludes historic LNG purchasing agreement with Shell. Embassy of Hungary Washington. URL: https://washington.mfa.gov.hu/eng/news/hungaryconcludes-historic-Ing-purchasing-agreement-with-shell

14. Joint U.S.-EU Statement following President Juncker's visit to the White House. European Commission. URL: https://ec.europa.eu/commission/ presscorner/detail/en/STATEMENT_18_4687

15. Leal-Arcas R. Natural Gas, US Shale Dynamics and Energy Security: A View from the European Union. In Raszewski S. (ed.) The International Political Economy of Oil and Gas. Palgrave MacMillan, 2018. P. 73-86.

16. Liquefied natural gas trade volume worldwide from 1970 to 2019 (in billion cubic meters). Statista. URL: https://www.statista.com/statistics/264000/globalIng-trade-volume-since-1970/

17. Meliksetian V. (2021). Why Asian LNG Prices Are Going Through The Roof. Oil Price. URL: https:// oilprice.com/Energy/Energy-General/Why-Asian-LNGPrices-Are-Going-Through-The-Roof.html

18. Memorandum of Cooperation Among The Republic of Poland, Ukraine and The United States of America On Enhancing Regional Security of Natural Gas Supply. US Department of Energy. URL: https://www.energy.gov/ia/ articles/memorandum-cooperation-among-republic-polandukraine-and-united-states-america-enhancing

19. Mitrova T. The New Russian Gas Export Strategy After the Ukraine Crisis. In Hafner M., Tagliapietra S.(eds). 
The European Gas Markets: Challenges and Opportunities. Palgrave Macmillan, 2017, P. 195-226.

20. O'Donnell T. (2018). Germany's Real LNG Strategy. Berlin Policy Journal. URL: https:// berlinpolicyjournal.com/germanys-real-Ing-strategy/

21. Projected regasification capacity of large-scale liquefied natural gas (LNG) terminals in Europe by development phase from 2020 to 2026 (in billion cubic meters). Statista. URL: https://www.statista.com/statistics/1101409/ Ing-terminals-regasification-capacity-outlook-europe/

22. Quarterly Report on European Gas Markets. Vol. 9, Iss. 4, fourth quarter of 2016. URL: https://ec.europa.eu/ energy/sites/default/files/gasmarketqreports_2016.zip

23. Quarterly Report on European Gas Markets with focus on the impact of global LNG markets on EU gas imports. Vol. 12, Iss. 4, fourth quarter of 2019. URL: https://ec.europa.eu/energy/sites/ener/files/quarterly report_on_european_gas_markets_q4_2019_final.pdf

24. Quarterly Report on European Gas Markets with focus on the impact of global LNG markets on EU gas imports. Vol. 13, Iss. 4, fourth quarter of 2020. URL: https://ec.europa.eu/energy/sites/default/files/quarterly report_on_european_gas_markets_q4_2020_final.pdf

25. Sampson J. (2021). Bulgartransgaz completes participation in Alexandroupolis LNG terminal. Gas World. URL: https://www.gasworld.com/bulgartransgaz-completesparticipation-in-alexandroupolis-Ing-terminal/2020414.article

26. Talus K. (2016). Introduction to EU Energy Law. Oxford University Press, 2016, 180 p.

27. US commits $\$ 1$ billion dollars to develop Central European infrastructure. Atlantic Council. URL: https://www.atlanticcouncil.org/news/press-releases/ us-commits-1-billion-dollars-to-develop-centraleuropean-infrastructure/

28. Vicari M. (2019). The American «New Energy Realism» And The Prospects Of US LNG In The EU. Vocal Europe. Policy Paper. 18 p.

29. Wemer D. (2019). The Three Seas Initiative explained. Atlantic Council. URL: https://www. atlanticcouncil.org/blogs/new-atlanticist/the-three-seasinitiative-explained-2/

30. Yafimava K. (2020). Finding a Home' for Global LNG in Europe: Understanding the Complexity of Access Rules for EU Import Terminals. Oxford Institute of Energy Studies. OEIS Paper, NG 157, January 2020. URL: https:// www.oxfordenergy.org/publications/finding-a-home-forglobal-Ing-in-europe-understanding-the-complexity-ofaccess-rules-for-eu-import-terminals/?v=35b5282113b8

31. Американська компанія відмовилася від ідеї поставок скрапленого газу в Україну. Економічна Правда. URL: https://www.epravda.com.ua/news/ 2020/09/11/665001/

32. «Маршал Василевский» отправился в Индию. Коммерсанть. URL: shorturl.at/bwLU4

33. НОВАТЭК предложил «Газпрому» помочь с Украиной. Коммерсанть. URL: https://www. kommersant.ru/doc/4018757

34. НОВАТЭК сгущает конкуренцию. РБК. URL: https://www.rbc.ru/newspaper/2019/12/24/5dfca3dc9a7 947a09a08fcd6

\section{REFERENCES:}

1. Bochkarev D. (2019). Floating Storage Regasification Unit (FSRU) in Kaliningrad: Scoring Several Goals with One Shot. Valdai Club. URL: https://valdaiclub.com/a/highlights/floating-storageregasification-unit-fsru/
2. Bordoff J., Losz A. (2016) If You Build It, Will They Come? The Competitiveness of US LNG in Overseas Markets. Center on Global Energy Policy of Columbia SIPA. URL: https://energypolicy.columbia.edu/ sites/default/files/Competitiveness $\% 20$ of\%20US\%20 LNG\%20in\%200verseas\%20Markets.pdf

3. Bros T. (2017). Global LNG Pricing Dynamics and Impact on Europe. In Hafner, Manfred; Tagliapietra, Simone (eds). The European Gas Markets: Challenges and Opportunities. Palgrave Macmillan, 2017. P. 179-193.

4. CEER response to the European Commission's strategy for liquefied natural gas and gas storage. Council of European Energy Regulators. URL: https:// www.ceer.eu/documents/104400/-/-/22e2218f-f1242d30-fabd-b8d031879278

5. Corbeau, A.-S. (2017). Global LNG Market Outlook and Repercussions for Europe. In Hafner M., Tagliapietra S. (eds). The European Gas Markets: Challenges and Opportunities. Palgrave Macmillan, 2017. P. 147-179.

6. Corbeau A.-S., Yermakov V. Will There Be a Price War Between Russian Pipeline Gas and US LNG in Europe? European Gas Hub. URL: https://www. europeangashub.com/wp-content/uploads/attach 664.pdf

7. Communication from the Commission to the European Parliament, the Council, the European Economic and Social Committee and the Committee of the Regions on an EU strategy for liquefied natural gas and gas storage. European Commission. URL: https:// ec.europa.eu/energy/sites/ener/files/documents/1_EN_ ACT part1 v10-1.pdf

8. Declaration of will to terminate Yamal Contract effective December 31, 2022. PGNIG. URL: http:// en.pgnig.pl/news/-/news-list/id/declaration-of-will-toterminate-yamal-contract-effective-december-31-2022/ newsGroupld/1910852

9. European Union imports of U.S. Liquefied Natural Gas (LNG) are on the rise. European Commission. URL: https://ec.europa.eu/commission/presscorner/detail/en/ IP $18 \quad 4920$

10. Gotev, G., Brzozowski, A. (2018). The Brief Three Seas, Two Leaders. Euractiv. URL: https:// www.euractiv.com/section/politics/news/the-brief-threeseas-two-leaders/

11. Gusilov E. (2019). Black Sea LNG: Dreams vs Reality. Romanian Energy Center. URL: https:// www.roec.biz/project/black-sea-Ing-dreams-vs-reality/

12. Hafner M., Tagliapetra S. (2017). The Role of Natural Gas in the EU Decarbonization Path. In Hafner, Manfred; Tagliapietra, Simone (eds). The European Gas Markets: Challenges and Opportunities. Palgrave Macmillan, 2017, P. 1-24.

13. Hungary concludes historic LNG purchasing agreement with Shell. Embassy of Hungary Washington. URL: https://washington.mfa.gov.hu/eng/news/hungaryconcludes-historic-Ing-purchasing-agreement-with-shell

14. Joint U.S.-EU Statement following President Juncker's visit to the White House. European Commission. URL: https://ec.europa.eu/commission/presscorner/detail/ en/STATEMENT 184687

15. Leal-Arcas $\bar{R}$. Natural Gas, US Shale Dynamics and Energy Security: A View from the European Union. In Raszewski S. (ed.) The International Political Economy of Oil and Gas. Palgrave MacMillan, 2018. P. 73-86.

16. Liquefied natural gas trade volume worldwide from 1970 to 2019 (in billion cubic meters). Statista. URL: https://www.statista.com/statistics/264000/globalIng-trade-volume-since-1970/ 
17. Meliksetian V. (2021). Why Asian LNG Prices Are Going Through The Roof. Oil Price. URL: https:// oilprice.com/Energy/Energy-General/Why-Asian-LNGPrices-Are-Going-Through-The-Roof.html

18. Memorandum of Cooperation Among The Republic of Poland, Ukraine and The United States of America On Enhancing Regional Security of Natural Gas Supply. US Department of Energy. URL: https://www.energy.gov/ia/ articles/memorandum-cooperation-among-republic-polandukraine-and-united-states-america-enhancing

19. Mitrova T. The New Russian Gas Export Strategy After the Ukraine Crisis. In Hafner M., Tagliapietra S. (eds). The European Gas Markets: Challenges and Opportunities. Palgrave Macmillan, 2017. P. 195-226.

20. O'Donnell T. (2018). Germany's Real LNG Strategy. Berlin Policy Journal. URL: https:// berlinpolicyjournal.com/germanys-real-Ing-strategy/

21 . Projected regasification capacity of largescale liquefied natural gas (LNG) terminals in Europe by development phase from 2020 to 2026 (in billion cubic meters). Statista. URL: https://www.statista.com/ statistics/1101409/lng-terminals-regasification-capacityoutlook-europe/

22. Quarterly Reporton European Gas Markets. Vol.9, Iss. 4, fourth quarter of 2016. URL: https://ec.europa.eu/ energy/sites/default/files/gasmarketqreports_2016.zip

23. Quarterly Report on European Gas Markets with focus on the impact of global LNG markets on EU gas imports. Vol. 12, Iss. 4, fourth quarter of 2019. URL: https://ec.europa.eu/energy/sites/ener/ files/quarterly_report_on_european_gas_markets q4_2019_final.pdf

24. Quarterly Report on European Gas Markets with focus on the impact of global LNG markets on EU gas imports. Vol. 13, Iss. 4, fourth quarter of 2020. URL: https://ec.europa.eu/energy/sites/default/files/quarterly_ report_on_european_gas_markets_q4_2020_final.pdf
25. Sampson J. (2021). Bulgartransgaz completes participation in Alexandroupolis LNG terminal. Gas World. URL: https://www.gasworld.com/bulgartransgazcompletes-participation-in-alexandroupolis-Ingterminal/2020414.article

26. Talus K. (2016). Introduction to EU Energy Law. Oxford University Press, 2016. 180 p.

27. US commits $\$ 1$ billion dollars to develop Central European infrastructure. Atlantic Council. URL: https://www. atlanticcouncil.org/news/press-releases/us-commits-1billion-dollars-to-develop-central-european-infrastructure/

28. Vicari M. (2019). The American «New Energy Realism» And The Prospects Of US LNG In The EU. Vocal Europe. Policy Paper. 18 p.

29. Wemer D. (2019). The Three Seas Initiative explained. Atlantic Council. URL: https://www. atlanticcouncil.org/blogs/new-atlanticist/the-three-seasinitiative-explained-2/

30. Yafimava K. (2020). Finding a Home' for Global LNG in Europe: Understanding the Complexity of Access Rules for EU Import Terminals. Oxford Institute of Energy Studies. OEIS Paper, NG 157, January 2020. URL: https:// www.oxfordenergy.org/publications/finding-a-home-forglobal-Ing-in-europe-understanding-the-complexity-ofaccess-rules-for-eu-import-terminals/?v=35b5282113b8

31. Amerykanska kompaniya vidmovylasya vid ideyi postavok skraplenogo gazu v Ukrainu. Ekonomichna Pravda. URL: https://www.epravda.com.ua/ news/2020/09/11/665001/ [in Ukrainian]

32. «Marshal Vasylevskyj» otpravylsya v Yndyyu. Kommersant. URL: shorturl.at/bwLU4 [in Russian]

33. NOVATEK predlozhyl «Gazpromu» pomoch s Ukrainoj. Kommersant. URL: https://www.kommersant.ru/ doc/4018757 [in Russian]

34. NOVATEK sgushchaet konkurencyyu. RBK. URL: https://www.rbc.ru/newspaper/2019/12/24/5dfca3 dc9a7947a09a08fcd6 [in Russian]

\section{Європейські ринки скрапленого природного газу: політичні виклики та енергетична дипломатія}

\section{Мошенець Ігор Олександрович}

аспірант центру безпекових студій Національного інституту стратегічних досліджень

вул. Пирогова, $7 \mathrm{a}$

Київ, Україна
Технологічні особливості транспортування скрапленого природного газу (СПГ) є вагомим чинником впливу на енергетичну геополітику завдяки створенню альтернативних до трубопроводів шляхів постачання. Метою цієї статmі є пояснення взаємозв'язку між діяльністю головних регіональних політичних акторів та економічним фрункціонуванням європейських ринків СПГ. Базовим для цього дослідження є метод відстеження процесів. Ключові тези нашого аналізу такі: 1) чотири базові фактори визначають майбутню роль СПГ в паливно-енергетичному балансі ЄС. Ними є: збільшення внутрішнього попиту через поступове виснаження власних газових родовищ та обмеження споживання вугілля; технологічний прорив американської індустрії сланчевого газу; різничя між ринковими цінами на СПГ в Європі та Східній Азії та між чінами на СПГ і постачання газу трубопроводами в Європі. Нині ЄС відіграє роль балансуючого регіону на світовому ринку, будучи менш привабливим у иіновому вимірі напрямком постачань, ніж Східна Азія; 2) повноваження Європейської Комісії щодо галузі СПГ стосувались часткового фрінансування інфраструктурних проектів та моніторингу дотримування ринковими гравцями норм європейського енергетичного законодавства. Брюссель вирішив уникати прямого політичного втру чання в галузь СПГ із метою визначення конкретних пріоритетних держав-експортерів. Країни-члени ЄС своєю чергою отримали змогу відігравати провідну роль у визначенні інораструктурних пріоритетів, що надало їм можливості інтегровувати свої стратегічні міркування щодо енергетичної сорери в ширший загальноєвропейський контекст вироблення політики; 3) експортери СПГ також можуть впливати на збільшення своі поставок методами енергетичної дипломатії. Утім, США та Росія мають різні стратегії просування свого експорту СПГ на європейські ринки. Енергетична дипломатія США концентрувалась на міждержавних зустрічах найвищого рівня. Натомість російська стратегія базувалась на корпоративних контактах без фрормального залучення інструментів державної дипломатії. Попри те, тісний формальний та неформальний контроль кремлівських політичних еліт за всіма активними у сорері СПГ компаніями зберігається. Ключові слова: Європейський Союз, СПГ, енергетична дипломатія, геополітика. 